\title{
ADVANCES IN ECOLOGICAL MODELLING OF SOIL PROPERTIES BY SELF-ORGANIZING FEATURE MAPS OF NATURAL ENVIRONMENT OF LOWER SILESIA (POLAND)
}

\author{
ANDRZEJ STANKIEWICZ, PIOTR KosibA \\ Department of Ecology, Biogeochemistry and Environmental Protection, \\ Institute of Plant Biology, Wroclaw University \\ Kanonia 6/8, 50-328 Wrocław, Poland \\ e-mail: stankiew@biol.uni.wroc.pl
}

(November 23, 2007. Accepted: April 3, 2009)

\begin{abstract}
The paper provides the use of self-organizing feature maps for determination of soil properties in its initial stage of development formed of massive rocks and how SOFM can be used for the study of environmental objects. The study area was Lower Silesia (Poland) overgrown with common, unique and protected vegetation of lichens, bryophytes and vascular plants. The parent rock of the studied soils consists of Miocene volcanites from the middle part of the Sudety Margin Fault. Soil samples were collected from 20 sites. The soil reaction $(\mathrm{pH})$ and concentrations of $\mathrm{Cd}, \mathrm{Co}, \mathrm{Cu}, \mathrm{Fe}, \mathrm{Mn}, \mathrm{Mo}, \mathrm{Ni}, \mathrm{Pb}, \mathrm{S}, \mathrm{Ti}, \mathrm{Zn}$ in surface soils were analyzed. Statistical analysis was carried out by one-way ANOVA. The SOFM was used to demonstrate the non-linear ordination and visualization of soil properties. The SOFM showed the influence of parent rock on soil chemical properties generated by it. SOFM appeared to be effective and proper/fit for phenomena and processes taking place in natural environment and is useful in ecology and ought to be taken into account as a possible tool of estimation of various plants and their biotopes. The model can be useful as alternative techniques in modelling the ecological complex data, and provide a novel framework for the discovery and forecasting of ecosystem structure and behaviours in response to environmental changes.
\end{abstract}

KEY WORDS: self-organizing feature maps, neural network, ecological modelling, soil composition, parent rock, basalt.

\section{INTRODUCTION}

Many adverse processes affect and modify the ecological functions of soils, and environment and human health is strongly dependent on the status of soils (Simpson 1996). The industrial, urban and traffic pollution sources reduce the surface under vegetation and soils (Oechtering 2000), and produce harmful effects causing devastation of the natural environment, contamination of soil and pollution of the atmosphere (Samecka-Cymerman et al. 2009).

Since many years, the area of Lower Silesia is influenced by pollution mainly from point-source emitters: Legnica-Głogów (copper industry) and Turów Basin (mining and energetic industry), as well as by urban-agglomeration, traffic and other small sources. Moreover, south-western Poland is additionally affected by trans-boundary dust-gaseous pollutions from Germany and the Czech Republic (Helios-Rybicka 1996).

The Tertiary basaltoids of Lower Silesia belong to eastern branch of the Bohemo-Silesian volcanic belt and vol- canic activity produced numerous basaltoid stratocones with or without central plugs and, often extensive, lava flows (Birkenmajer et al. 2007). The volcanic rocks are mostly basanites and tephrites, more rarely nephelinites and alkali basalts as well as trachytes and latites (Kozłowska-Koch 1987). The Tertiary volcanic rocks occurring in Germany, Poland and the Czech Republic are often termed the Central European Tertiary intra-plate volcanic province (Puziewicz 2005: Birkenmajer et al. 2007). Their character was earlier noted and commented by Wocke (1927) and Knörrlich (1928), and they were also the objectives of geological studies by Kabata-Pendias (1965), Białowolska (1980), Kozłowska-Koch (1987). Kozłowska-Koch (1987) and Birkenmajer et al. (2007; and other references cited by those authors in the paper), carried out the division of Lower Silesian Tertiary volcanites in respect of their chemical composition and distinguished among them the basanite, basalt Nen, tephrite, basalt Oln, havaite, basalt and picrobasalt - TAS division (Total Alkali Silica) (Le Bas and Streckeisen (1991). 
In the complex of soil-generating factors a fundamental part in formation of wastes and soils plays the parental rock as its structure, mineral composition, chemical and physical properties are conditioning the rate of transformations and the course of soil-generating processes taking place in the most external layer of the lithosphere. For plants developing in extreme soil conditions of particular importance are the weathering of primary minerals of the solid rock, under influence of soil-generating factors, and the origin of secondary clayey minerals (Bogda 1973).

The characteristic soils formed in the area of Lower Silesia from basalts, are overgrown with common but also unique and protected vegetation, for example: Woodsia alpina, Saxifraga nivalis, S. moschata subsp. basaltica (Fabiszewski 1985). Here originates the habitat of lithophytes, among which the chasmophytes are of particular importance and do not appear beyond that type of soil, i.e.: Asplenium septentrionale, A. trichomanes, Polypodium vulgare, Dryopteris filix-mas, Sedum acre, Thymus pulegioides, Hieracium pilosella. Of particular importance are those of scientific and scenery value, such as: Dianthus superbus, Cyprypedium calceolus, Gentianella amarella, and representatives of the genera Dactylorhiza, Cephalanthera, Orchis, and other plants: Achillea pannonica, Alyssum alyssoides, Camelina microcarpa, Carduus nutans, Centaurea rhenana, Petrorhagia prolifera, Phleum phleoides, Scabiosa columbaria, Trifolium striatum (Kwiatkowski 1999; Mróz 2001), and other important communities of lichens (Kossowska and Fabiszewski 2004), bryophytes and vascular plants (Fabiszewski and Wojtuń 2001; Fabiszewski and Kwiatkowski 2002). Moreover, observed are also the different synecological relations of plants as alliances or communities (Anioł-Kwiatkowska and Świerkosz 1990).

Researchers use a lot of numerical methods, mainly classical ones, but also techniques based on artificial intelligence (ANN's - artificial neural networks) (Sokołowski 2002). Nowadays, in case of ecological studies greater attention is drawn to artificial neural networks, and Koho- nen's ANN is routinely used for ordination and visualization of complex ecological data. Its offers an attractive solution to lots of problems in many critical applications, presently used in many modelling tasks (Recknagel 2001).

For many years the commonly used technique of mathematical description of various objects and processes consisted in linear modelling. However, there where linear-approximation methods cannot be used, the neural networks may occur to be the fastest and most convenient solution of such problems. Neural networks give the possibility to control the complex problem of multidimensionality, which hinders the testing of modelling non-linear functions with a high number of independent variables. In such cases the use of Kohonen's networks is particularly advantageous (Tadeusiewicz 2000; Kohonen 2001).

In the present paper the hypothesis has been put forward, that the neural-network method (SOFM) does provide a picture of influence of a given type of parent rock upon properties of the analyzed soils.

\section{MATERIALS AND METHODS}

\section{Study area and object of interest}

The investigations have been carried out in the year 2006 from outcrops of Miocene basaltoids in the south-western part of the Poland (Lower Silesia). Established were 20 sites which are located between $51^{\circ} 09^{\prime}$ and $15^{\circ} 34^{\prime} \mathrm{N}$, and $50^{\circ} 57^{\prime}$ and $16^{\circ} 20^{\prime} \mathrm{E}$ (Fig. 1). Subject to analysis were 20 soil samples from around mountain: Obłoga - 1 (51 00 ' 42 ', N; $16^{\circ} 03$ '54', E), Góra św. Jerzego - 2 (51 $59^{\circ} 36^{\prime \prime} \mathrm{N} ; 16^{\circ} 18$ '21' 'E), Krzyżowa Góra n/Strzegom - 3 (5058'28 N; $16^{\circ} 20^{\prime} 04^{\prime}$ ' E ), Graniczna - 4 (5059'39', $\left.\mathrm{N} ; 16^{\circ} 21^{\prime} 43^{\prime}, \mathrm{E}\right)$, Żarecka Kopa - 5 (51 ${ }^{\circ} 05^{\prime} 06^{\prime}, \mathrm{N}$; $\left.16^{\circ} 07^{\prime} 40^{\prime}, \mathrm{E}\right)$, Trzej Królowie - 6 (51 $05^{\circ} 31^{\prime}, \mathrm{N}$;

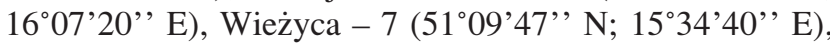
Ostrzyca $-8\left(51^{\circ} 03^{\prime} 54^{\prime \prime} \mathrm{N} ; 5^{\circ} 45^{\prime} 11 \mathrm{E}\right)$, Grodziec - 9 $\left(51^{\circ} 10^{\prime} 00^{\prime}, \mathrm{N} ; 5^{\circ} 45^{\prime} 02^{\prime}, \mathrm{E}\right)$, Wilcza Góra - 10

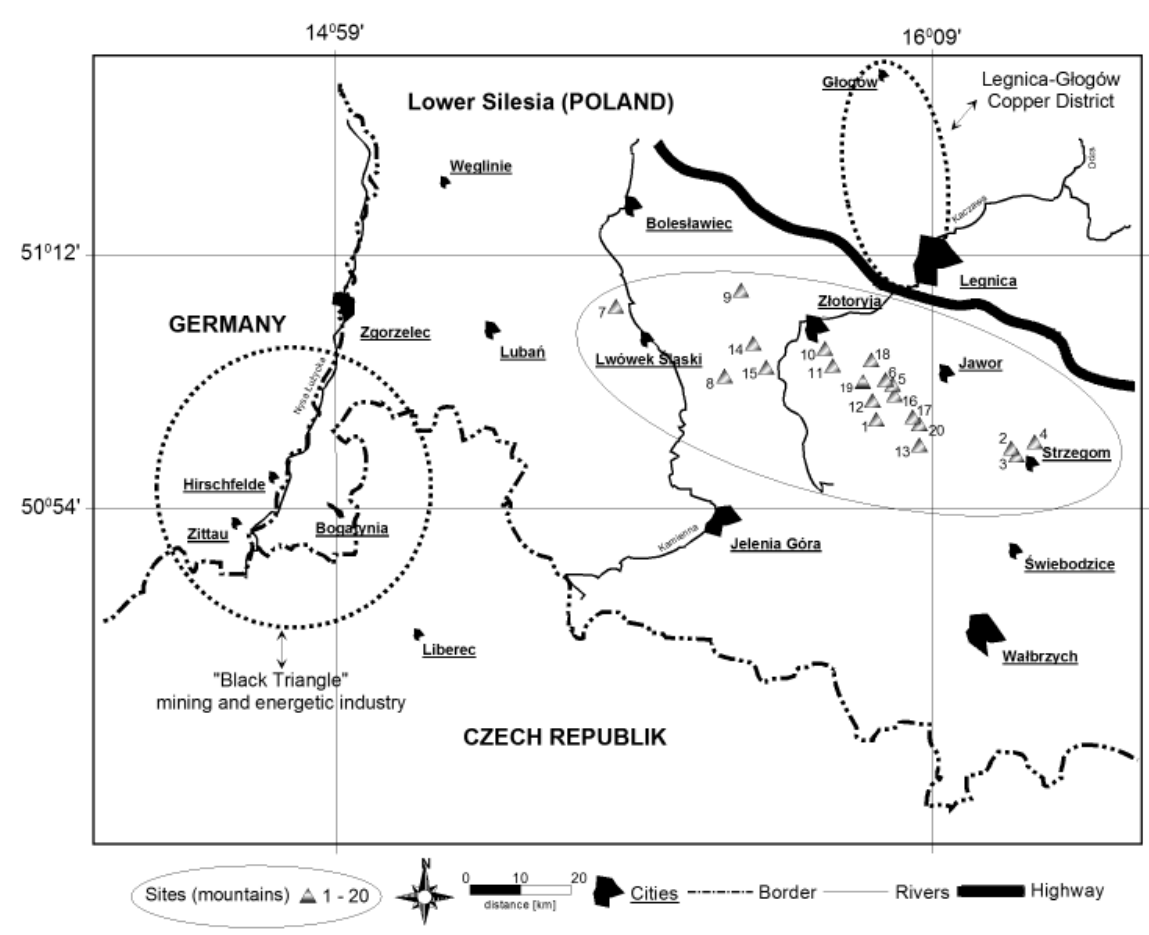

Fig. 1. Localization of the sampling sites in south-western Poland (Lower Silesia). 
(51 $06^{\prime} 19^{\prime \prime} \mathrm{N} ; 15^{\circ} 54^{\prime} 59^{\prime \prime}$ E), Trupień - $11\left(51^{\circ} 03\right.$ '52', N;

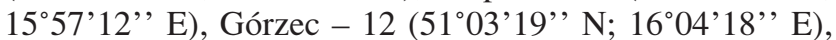
Rodogost - 13 (51 ${ }^{\circ} 00^{\prime} 09^{\prime}$ ' N; 16 $16^{\circ} 07^{\prime} 58^{\prime}$ ' E), Kamienna Góra - 14 (51 ${ }^{\circ} 06^{\prime} 22^{\prime}$ ' N; 15 49'35 E), Jeziorna - 15 $\left(51^{\circ} 05^{\prime} 42^{\prime}, \mathrm{N}\right.$; $\left.15^{\circ} 51^{\prime} 48^{\prime}, \mathrm{E}\right)$, Winnica $-16\left(51^{\circ} 03^{\prime} 37^{\prime}, \mathrm{N}\right.$;

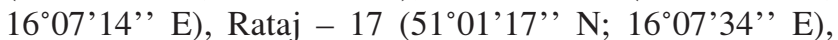
Krzyżowa Góra n/Sichów - 18 (51 ${ }^{\circ} 04^{\prime} 31^{\prime}$ ' N; $16^{\circ} 03^{\prime} 04$ ', E), Czartowska Skała - 19 (51 02 '14', N; $16^{\circ} 01^{\prime} 41^{\prime \prime}$ E), Bazaltowa Góra - $20\left(51^{\circ} 00^{\prime} 41^{\prime \prime}\right.$ N; $16^{\circ} 07^{\prime} 53$ E) type of parent rock see note in Table 1).

According to the Polish Soils Classification (Trzciński 1989), these soils belong to section lithogenic soils (I), of order poorly developed mineral non-carbonateless soils (IA), of type rocky soils in the initial developmental stage (IA1), subtype erosion soils (a). The morphological structure of the analyzed soils is as follows: (A)C-R. Characteristic of these soils is the dominating influence of parent rock as the soil-generating factor. It consists in our case of ultra alkaline basic solid rock. The initial humus level (A)C, of $5 \mathrm{~cm}$ thickness, includes relatively much humus, from 2.91 to $8.00 \%$.

\section{Chemical analyses of soils}

Three samples of soils were taken from each site, from a depth of 0-10 cm, and after removing litter and other debris were dried at $50^{\circ} \mathrm{C}$. Soil samples were homogenized with a mortar and sifted using a $2 \mathrm{~mm}$ sieve. The trace elements were extracted using microwave MARS-5 CEM Corp. digestion with $\mathrm{HNO}_{3}$ and $\mathrm{HCl}$ in Teflon vessels. The total content of Fe, Mn, Zn were determined by FAAS (flame atomic absorption spectrophotometry - GBC Scientific Equipment Pty. Ltd. Model AVANTA PM) and Cd, Co, $\mathrm{Cu}, \mathrm{Mo}, \mathrm{Ni}, \mathrm{Pb}$, Ti by ETAAS (electrothermal atomic absorption spectrophotometry - GBC Scientific Equipment Pty. Ltd. Model AVANTA PM using the attachment Model GF 3000). The total S content was determined by the SC-114DR LECO Corp. The soil reaction (pH) was mea- sured in distilled water and in $1 \mathrm{~mol} \mathrm{KCI}$ by means of the pH meter CP-104. All elements were measured against standards and blanks prepared in concentrated nitric and hydrochloric acid. Analyses were carried out in three measuring repetitions. The element concentrations are expressed as $\mathrm{mg}^{*} \mathrm{~kg}^{-1}$ air-dried soil mass.

\section{Statistical analyses}

The obtained results of chemical analyses of soil samples were expressed as arithmetic means, standard deviations $( \pm \mathrm{SD})$, minimum, maximum and coefficients of variation (V) values. On the basis of results the statistical analyses were performed. The fitting distribution of the empirical data was verified to the normal one by the ShapiroWilk's test, and the homogeneity of variances were checked up by Levene's test. The results showed compatibility with the normal distribution. Hence, the one-way ANOVA with the F-test were used.

The SOFM was used (Kohonen 2001), to classify the sites in respect of contents of chemical elements in soil samples. The structure of the SOFM consists of two layers of neurons connected by weight (connection intensities). The input layer consisted of 20 input neurons (sites) and every neuron is represented by 11 chemical elements of soils. The scheme of SOFM with Kohonen's algorithm is presented in Figure 2.

The unsupervised training of the net was performed on the basis of dataset and the classical Kohonen's algorithm. The net was initiated by the random-Gaussian method. The learning phase has been specified into 100 steps (EPOCHs) for the ordination phase and 1000 steps for the tuning phase. After the learning phase, it was found by mean of the genetic algorithm, that all the initial data are significant (Goldberg 1989). Finally, the Kohonen's topological map $5 \times 5$ has been designed. The output layer consisted of 25 neurons (visualized by hexagonal cells) organized in an array with five rows and five columns. The networks were

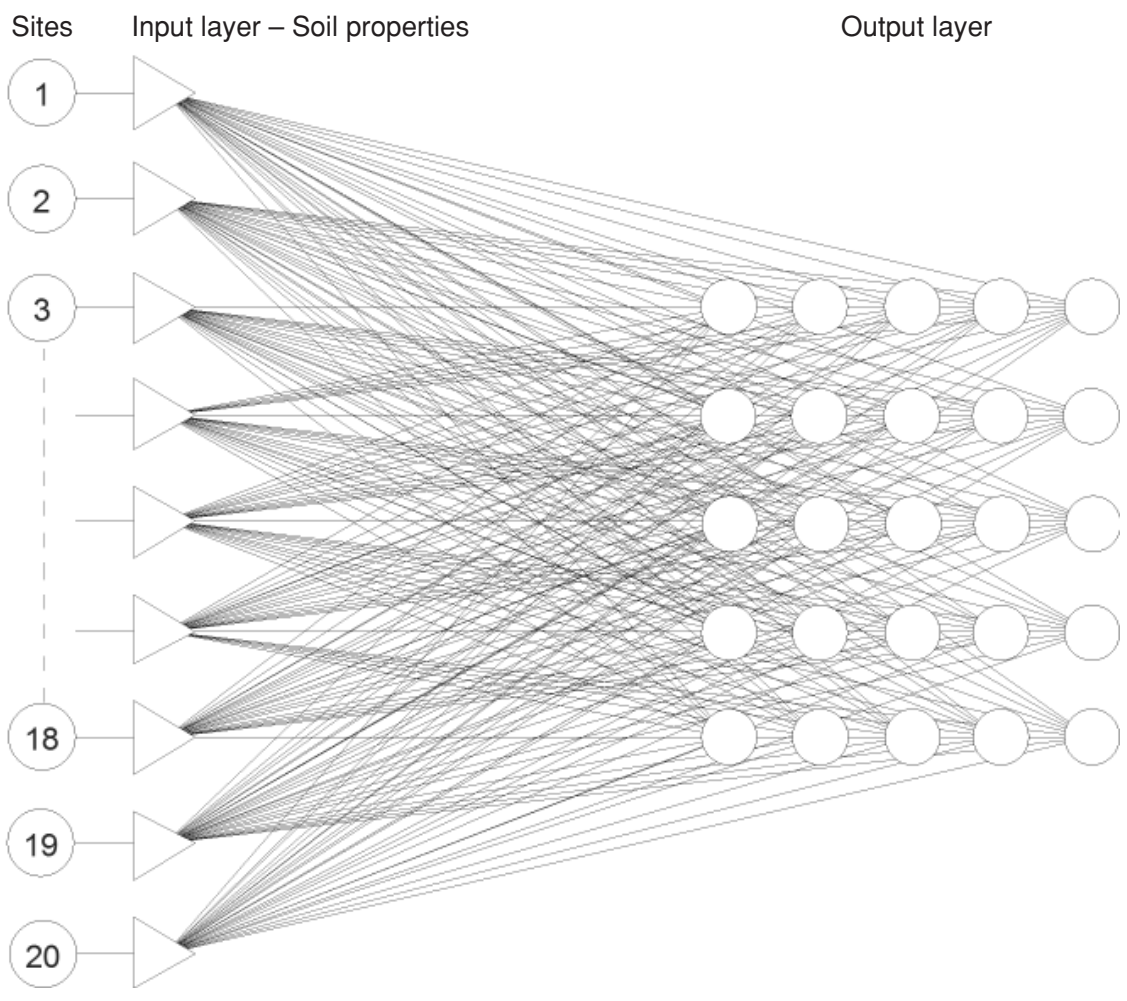

Fig. 2. Scheme of SOFM with Kohonen's algorithm. 


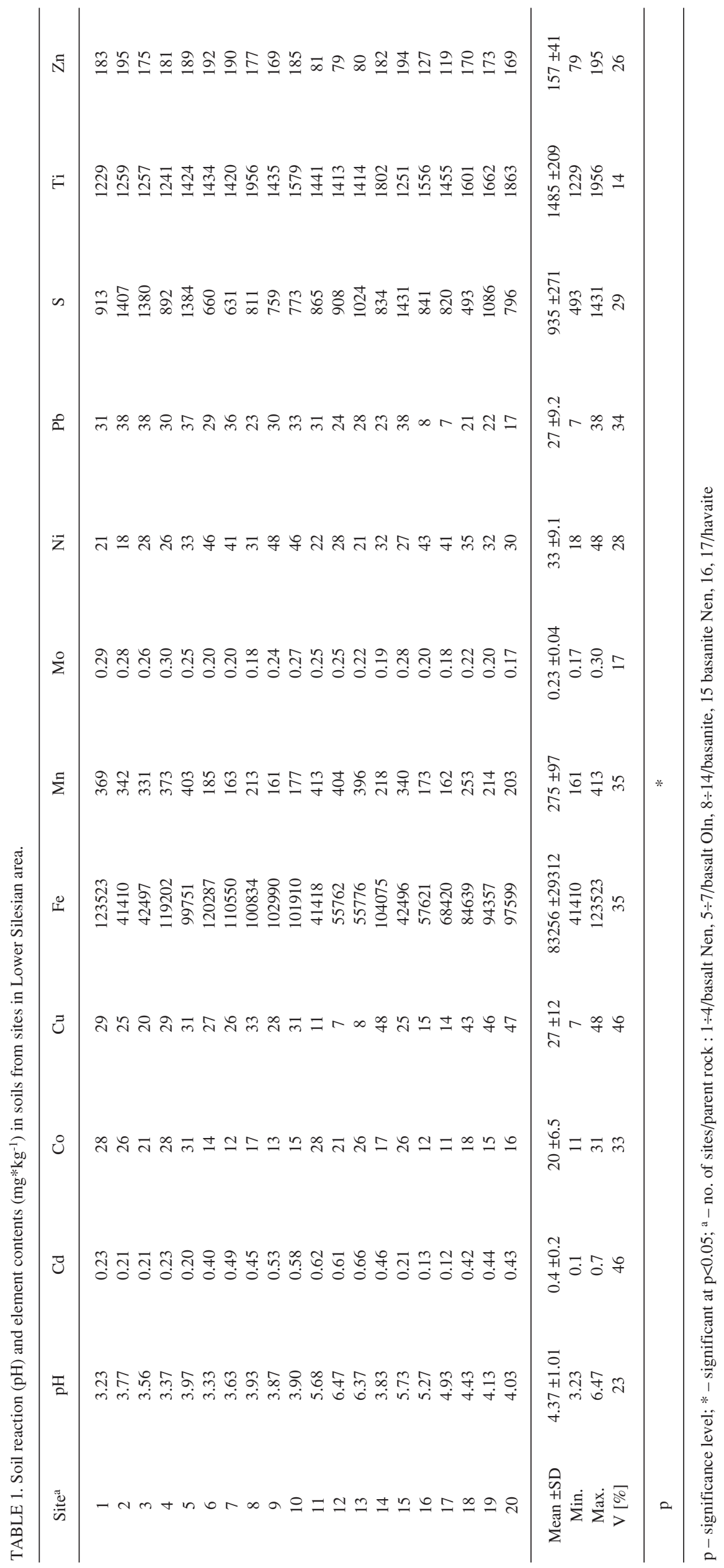

created according to the scheme "the winner takes all". The obtained Kohonen's topological map showed the neurons or groups of neurons activated by the particular investigated cases (sites).

The verification of the obtained results was carried out at significance level of 0.05 according to the statistical methods and principles given by Sokal and Rohlf (2003). For all calculations, the STATISTICA 8.0 program (StatSoft, Inc. 2007) was used. The numerical techniques applied in ecological investigations, i.e. collection of quantitative information on objects analysis and interpretation of results, as well as all numerical procedures, were based on principles given by Brower et al. (1998).

\section{RESULTS AND DISCUSSION}

The examined sites differ significantly between themselves in respect of $\mathrm{pH}$ and element contents in soils and show wide ranges between the sites (Table 1).

Values of soil $\mathrm{pH}$ present different acidity, i.e. from very acid to neutral reaction $(3.23 \div 6.87)$. Ranges and average values of elements are similar in most of cases in relation to natural element concentrations. The elements do not exceed the range values in different type of surface soils and in various soils of Poland (range; mean or $1 \mathrm{~m}$ - lack of mean, in parentheses as $\left.\mathrm{mg}^{*} \mathrm{~kg}^{-1}\right)$ for $\mathrm{Cd}$ $(0.01 \div 0.96 ; 0.34)$, Co $(0.1 \div 34$; $29.1), \quad \mathrm{Cu}(1 \div 113 ; 13.2), \quad \mathrm{Fe}$ $(3200 \div 27800 ; 1 \mathrm{~m})$, Mn $(15 \div 7750$; 421.1), Mo $(0.1 \div 6 ; \mathrm{lm})$, Ni $(0.2 \div 104$; 15.3), $\quad \mathrm{Pb} \quad(5 \div 286 ; 21.3), \quad \mathrm{Ti}$ $(80 \div 8000 ; 2920), \mathrm{Zn}(3 \div 762 ; 52.5)$ (Kabata-Pendias 2001a), and for S $(200 \div 2000$; lm) (Markert 1992), except values of Mo and $\mathrm{Ti}$, which are very close to the lower limit .

The contents of elements in analyzed soils, also are characterized by a wide range of the variability coefficient. The lower values of the variability coefficient have $\mathrm{Ti}(14 \%)$ and Mo (17\%), whereas, the remaining elements are characterized by higher values $(>25 \%)$. The variability coefficient shows the relation of intensity of additional causes to the main ones and the amount up to 5\% describes perfectly the trait's stabili- 
ty, $\leq 10 \%$ very good, $\leq 15 \%$ good, $\leq 20 \%$ sufficiently, $\leq 25 \%$ insufficiently and over 25\% wrongly (Zając 1994; Krzywiecka 1989, see in paper by Kosiba 2008). In our case, one may suppose, that the high value of the variability coefficient $(>25 \%)$ for $\mathrm{Cd}, \mathrm{Co}, \mathrm{Cu}, \mathrm{Fe}, \mathrm{Mn}, \mathrm{Ni}, \mathrm{Pb}, \mathrm{S}, \mathrm{Zn}$ is modified by pollution in relation to the low variability value for Mo and $\mathrm{Ti}(<20 \%)$, of which the natural element contents in soils is inherited from parent rock. According to Kabata-Pendias (2001b), several natural and anthropogenic factors are known to affect the behaviour of elements, especially trace metals, which are very variable under changeable conditions of the soil-plant transfer chain. Thus, only variability of $\mathrm{Ti}$ and Mo contents represent a good and sufficient permanency, respectively, and their concentrations in soils are not affected by the above factors. Moreover, Mo content of soil usually resembles that of their parent rock and shows its association with granitic and other acid magmatic rock, and is least soluble in acid soils. Ti is a common constituent of rocks, very resistant to weathering, therefore, its occurs practically undecomposed in soils, and, like in case of Mo, Ti is least soluble in acid soils (Kabata-Pendias 2001a).

The natural element contents of soil is connected with parent rock. However, due to widespread pollution, most soils are very likely to be enriched with some elements, especially the top layer in the south-western industrial area of Poland (Kabata-Pendias 2001b). This author shows the classification system of soil pollution in Poland in respect of $\mathrm{Cd}, \mathrm{Cu}, \mathrm{Cr}, \mathrm{Ni}, \mathrm{Pb}, \mathrm{Zn}$ contents. For six classes (0, I, II, III, IV, V), three groups of soils were distinguished, e.g., sandy and acid (AG), medium and acid (BG), clay or orga- nic-rich and neutral (CG). The assessment of trace metal contents, according to the classification system, indicates that in over $90 \%$ of soils the concentrations of these metals do not increase above background level.

Regarding that classification and using as basis the range of the $\mathrm{pH}$ reaction, the analysed soils can be rated among the $\mathrm{BG}$ group (very acid $-\mathrm{pH}<4.5$ slightly acid $-\mathrm{pH}$ $5.6 \div 6.5$ ) and answer the classes 0 and I of the lowest contents of $\mathrm{Cd}, \mathrm{Cu}, \mathrm{Ni}, \mathrm{Zn}$, and the class 0 of lowest content of $\mathrm{Pb}$. According to that classification, the analysed soils can be recognized as clean and relatively clean, and as mentioned by Kabata-Pendias (2001b), two soil classes: 0 and I, of background and slightly elevated metal contents, respectively, are accepted for evaluation of environmental and farming values.

The first SOFM (Fig. 3) presents the clustering of various subsoil types by means of the data, describing the Miocene vulcanites of Lower Silesia according to the TAS division (Kozłowska-Koch 1987).

For supervised learning used were the results of chemical analyses of basalt waste from 89 sites distributed along the Sudety Mts. marginal fault (Kozłowska-Koch 1987). This extent of the SOFM, i. e. $5 \times 5$ is best imitated by TAS devision. After starting the network, using the genetic algorithm, it was found that all input data are significant. The unsupervised-learning method was carried out. In that way, the Kohonen's topologic map was obtained, on which the neurons or groups of neurons activated by the particular sites are clearly visible. Distinguished were: basalt Nen, nephelinite, basalt Oln and picrobasalt Nen activated in single neurons. The havaite makes a group of 2 neurons, and

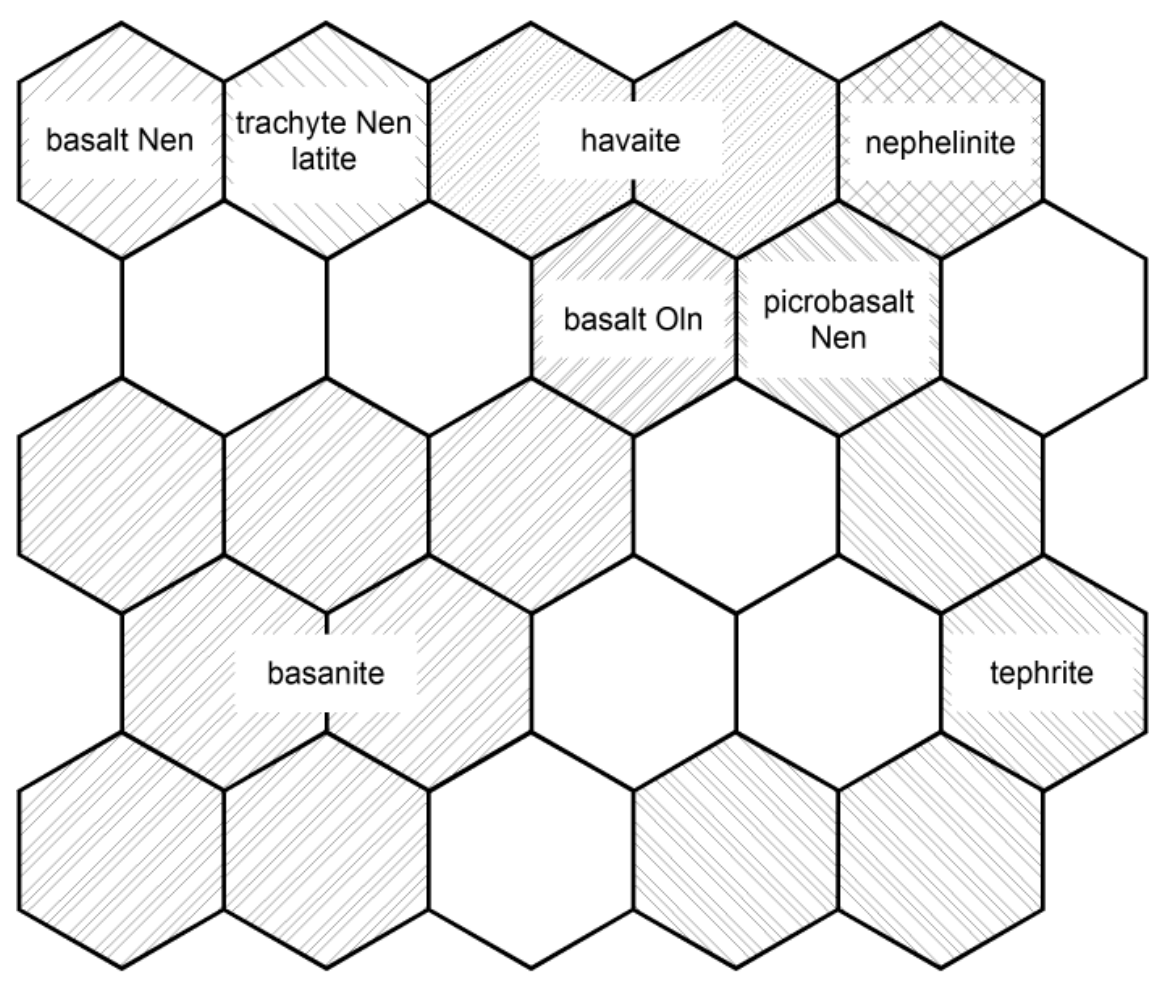

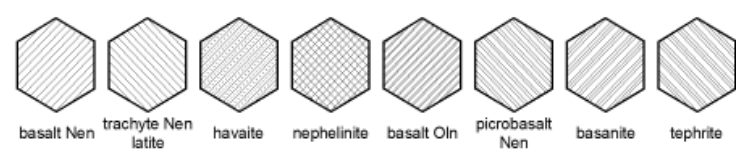

Fig. 3. Hexagonal topological SOFM of soil types in respect of chemical analyses of basalt waste along the Sudety Mountains Marginal Fault - according to data and TAS division. 
basanite and tephrite make a group of 7 neurons and 4 neurons, respectively, as separate units. An exception on the topologic map under discussion is a neuron activated simultaneously by sites formed of trachyte Nen latite. However, according to Kozłowska-Koch (1987), these are rocks similar to each other in respect of chemical and mineralogical composition. Next, the SOFM was "written down" into the file.

After learning, the new dataset and components were introduced to the received SOFM model. The unsupervised learning method was used to obtain SOFM's topological maps, clearly showing the neurons and group of neurons activated by the particular sites. The SOFM was used to identify groups of similar sites consisting of two types of units: the input layer is connected to each vector of the dataset (20 sites and 11 chemical elements), and the output layer forms a two-dimensional array of nodes. In the output layer, the units of the grid give a representation of distribution of sample units in an ordered way. These maps show the neurons/groups of neurons activated by the particular investigated sites/group of sites. The constructed self-organizing feature map is of the same dimension $(5 \times 5)$, as in case of Figure 3. The SOFM presented in Figure 4 shows a map identifying sites with similar soil element concentrations with a map identifying properties of subsoil types according to TAS division.

In the resulting SOFM, each cell represents a neuron. Sampling sites within one neuron are the most similar, and sites in neighboring neurons are more similar than sites in more distant neurons. The two maps of SOFM (Figs 3 and 4) clearly correspond with themselves. Neurons of studied sites correspond with neurons of parent rock TAS division map and the worked out model shows, that the parent rock exerts a significant influence on content of analyzed elements in them.

A similar technique with use of SOFM was applied by Giraudel and Lek (2001) for ordination of ecological communities, Lee and Scholz (2006) for assessment of SOFM as an alternative method versus classical for constructed treatment of wetlands, Kosiba and Stankiewicz (2007) used SOFM for modelling Utricularia species microhabitats, Samecka-Cymerman et al. (2007) for classification of the relation between chemical compositions of aquatic bryophytes and streambeds and Samecka-Cymerman et al. (2009) suggested a new form of data presentation in the form of self-organizing feature maps in bioindication studies with Brachythecium rutabulum around a copper smelter in Legnica. These authors and Tadeusiewicz (2000) proved the importance of SOFM and recommend it as a good tool in ecological modelling, which can be used in various fields of applied ecology.

\section{CONCLUSIONS}

On the basis of results and all the points discussed above it can be concluded, that:

- the soils studied on the territory of Lower Silesia appeared not to be subject to direct impact of contamination. The contents of elements in these soils correspond with clean or fairly clean soils, i.e., the classes $\mathrm{O}$ and I according to the classification of soil contamination,

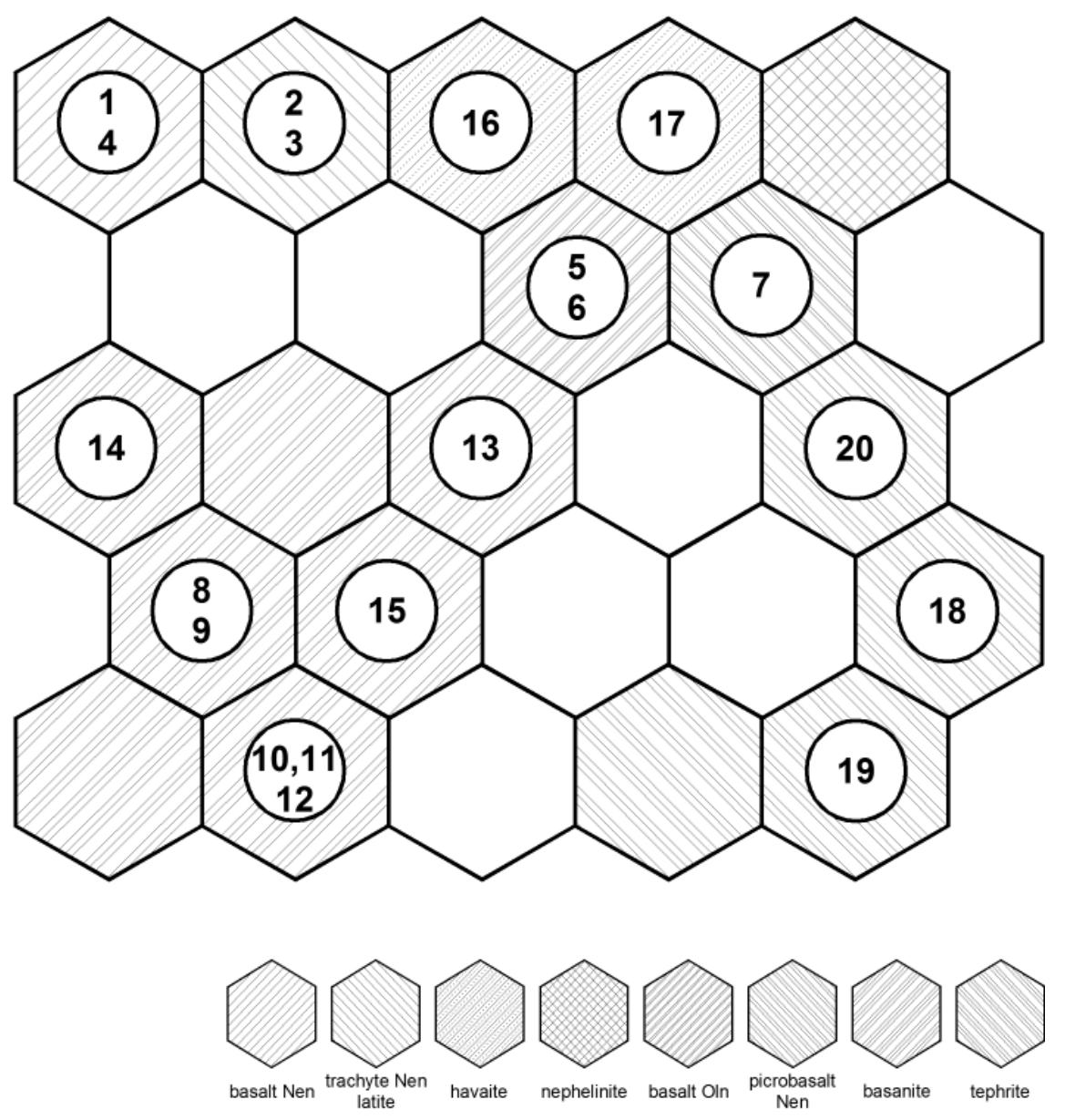

Fig. 4. Hexagonal topological SOFM of element concentrations in analyzed soils on the area of Lower Silesia (note: $\bigcirc-$ no. of site). 
- these soils are characterized by a high variation (>25\%) of $\mathrm{Cd}, \mathrm{Co}, \mathrm{Cu}, \mathrm{Fe}, \mathrm{Mn}, \mathrm{Ni}, \mathrm{Pb}, \mathrm{S}, \mathrm{Zn}$ contents, of which the natural content, inherited from the parent rock is modified, though in a small degree, by contamination, and the low variation $(<20 \%)$ of Mo and $\mathrm{Ti}$, of which natural element contents is inherited mainly from parent rock,

- these soils may serve as valuable community habitats for introduction and reintroduction of plants, and their chemical properties can be a determinant for other areas, mainly in order to enrich their natural values,

- the self-organizing feature maps (SOFM) of the analyzed soils and the Total Alkali Silica (TAS) devision show a considerable similarity in respect of chemical properties,

- SOFM appeared to be effective and proper/fit for phenomena and processes taking place in natural environment and is useful in ecology. Thus, it ought to be taken into account as a possible tool of estimation of various plants and their community habitats,

- the introduction of new data and components to the SOFM model enables to anticipate and to simulate various phenomena and processes taking place in nature.

\section{LITERATURE CITED}

ANIOŁ-KWIATKOWSKA J., ŚWIERKOSZ K. 1990. Flora i roślinność rezerwatu "Ostrzyca Proboszczowicka" oraz jego otoczenia. Acta Univ. Wratisl., No. 1538, Prace Bot. 48: 45-115. (in Polish with English summary)

BIAŁOWOLSKA A. 1980. Geochemiczna charakterystyka niektórych bazaltoidów Dolnego Śląska i ich ultramafitowych enklaw. Arch. Miner., 36: 107-163. (in Polish with English summary)

BIRKENMAJER K., PÉCSKAY Z., GRABOWSKI J., LORENC M.W., ZAGOŻDŻON P. 2007. Radiometric dating of the tertiary volcanics in Lower Silesia, Poland. V. K-Ar and palaeomagnetic data from late oligocene to early miocene basaltic rocks of the North-Sudetic Depression. Ann. Soc. Geol. Pol., 77: 1-16.

BOGDA A. 1973. Mineralogiczne i mikromorfologiczne badania produktów wietrzenia niektórych magmowych skał macierzystych gleb występujących w Sudetach. Rocz. Gleb., 44, 2: 85132. (in Polish)

BROWER J.E., ZAR J.H., von ENDE C.N. 1998. Field and laboratory methods for general ecology. WCB/McGraw-Hill, Boston, Massechusetts Burr Ridge, Illinois Dubuque, Iowa Madison, Wisconsin New York, New York San Francisco, California St. Louis, Missouri.

FABISZEWSKI J. 1985. Szata roślinna. In: Karkonosze polskie, Jahn A. (ed.). Zakł. Narod. im. Ossolińskich, Wrocław, pp. 53-76. (in Polish)

FABISZEWSKI J., KWIATKOWSKI P. 2002. Threatened vascular plants of the Sudeten Mountains. Acta Soc. Bot. Pol., 71, 4: 339-350.

FABISZEWSKI J., WOJTUŃ B. 2001. Contemporary floristic changes in the Karkonosze Mts. Acta Soc. Bot. Pol., 70, 3: 237-245.

GIRAUDEL J.L., LEK S. 2001. A comparison of self-organizing map algorithm and some conventional statistical methods for ecological community ordination. Ecol. Model., 146: 329-339.

GOLDBERG D.E. 1989. Genetic algorithms in search, optimization, and machine learning. Addison-Wesley, Reading, MA.

HELIOS-RYBICKA E. 1996. Impact of mining and metallurgical industries on the environment in Poland. Appl. Geochem., 11: 3-9.
KABATA-PENDIAS A. 1965. Badania geochemiczno-mineralogiczne gleb wytworzonych z granitów i bazaltów Dolnego Śląska. Rocz. Nauk Rol., 90, 1: 1-60 (in Polish).

KABATA-PENDIAS A. 2001a. Trace Elements in Soils and Plants. Third Edition, CRC Press, USA.

KABATA-PENDIAS A. 2001b. Trace metals in soils - a current issue in Poland. In: Studies on plant ecology, Samecka-Cymerman A. (ed.). Acta Univ. Wratisl., No. 2317, Prace Bot., 79: 13-20.

KNÖRRLICH G. 1928. Der Heimat Bild. Heimatbusch des Kreises Golberg - Haynau. Druch und Verlag, Buchdruckerei Oskar Heinze, Liegnitz.

KOHONEN T. 2001. Self-Organizing Maps. Springer-Verlag, Berlin, Heidelberg Series in Information Sciences, Vol. 30, Berlin, Springer-Verlag.

KOSIBA P. 2008. Variability of morphometric leaf traits in small-leaved linden (Tilia cordata Mill.) under the influence of air pollution. Acta Soc. Bot. Pol., 77, 2: 125-137.

KOSIBA P., STANKIEWICZ A. 2007. Water trophicity of Utricularia microhabitats identified by means of SOFM as a tool in ecological modelling. Acta Soc. Bot. Pol., 76, 3: 255-261.

KOSSOWSKA M., FABISZEWSKI J. 2004. Threatened lichens of Lower Silesia, Poland. Acta Soc. Bot. Pol., 73, 2: 139-150.

KOZŁOWSKA-KOCH M. 1987. Klasyfikacja i nomenklatura trzeciorzędowych wulkanitów Dolnego Śląska i Śląska Opolskiego. Arch. Miner., 42: 1-107. (in Polish with English summary)

KWIATKOWSKI P. 1999. Przyrodnicze zagospodarowanie poeksploatacyjnych wyrobisk wapienia i bazaltu w Górach Kaczawskich. In: Zagospodarowanie wyrobisk, Malewski J. (ed.). Oficyna Wydawnicza Politechniki Wrocławskiej, Wrocław. pp. 109-125. (in Polish with English summary)

LE BAS M.J., STRECKEISEN A.L. 1991. The IUGS systematics of igneous rocks. J. Geol. Soc. London, 148: 825-833.

LEE B.H., SCHOLZ M. 2006. A comparative study: Prediction of constructed treatment wetland performance with k-nearest neighbors and neural networks. Water, Air Soil Pollut., 174: 279-301.

MARKERT B.A. 1992. Presence and significance of naturally occurring chemical elements of the periodic system in the plant organism and consequences for future investigations on inorganic environmental chemistry in ecosystems. Vegetatio, 103: $1-30$.

MRÓZ L. 2001. Dynamika liczebności populacji storczyków na Czartowskiej Skale na Pogórzu Kaczawskim. In: Studia nad ekologią roślin, Samecka-Cymerman A. (ed.). Acta Univ. Wratisl., No. 2317, Prace Bot., 79: 169-17. (in Polish with English summary)

OECHTERING E. 2000. Soil Sealing in the city of Hamburg 1986 and 1999. Proceedings First International Conference Soil of Urban, Industrial, Traffic and Mining Areas, Burghardt W., Dornauf C. (eds), Essen 12-18 July, Vol. III, pp. 641-645.

PUZIEWICZ J. 2005. Litospheric mantle beneath SW Poland. Mineralogical Society of Poland - Special Papers, 25: 184$-187$.

RECKNAGEL F. 2001. Applications of machine learning to ecological modelling. Ecol. Model., 146: 303-310.

SAMECKA-CYMERMAN A., STANKIEWICZ. A., KOLON K., KEMPERS A.J. 2007. Self-organizing feature map (neural networks) as a tool in classification of the relations between chemical composition if aquatic bryophytes and type of streambeds in the Tatra national park in Poland. Chemosphere, 67, 5: 954-960.

SAMECKA-CYMERMAN A., STANKIEWICZ A., KOLON K., KEMPERS A.J. 2009. Bioindication of Trace Metals in Brachythecium retabulum Around a Copper Smelter in Legnica (Southwest Poland): Use of a New Form of Data Presentation In the Form of a Self-Organizing Feature Map. Arch. Environ. Contam. Toxicol., DOI 10.1007/s00244-008-9249-8. 
SIMPSON T. 1996. Urban soil. In: Urban Geoscience, McCall G.J.H., De Mulder E.F.J., Markert B.R. (eds), pp. 35-60.

SOKAL R.R., ROHLF F.J. 2003. Biometry. The principles and practice if statistics in biological research. W. H. Freeman \& Company, New York.

SOKOŁOWSKI A. 2002. Metody stosowane w data mining. In: Data mining - metody i przykłady. StatSoft Polska Sp. z o.o., Kraków, pp. 5-12. (in Polish)
STATSOFT, INC. 2007. Statistica (data analysis software system), version 8.0. (www.statsoft.com).

TADEUSIEWICZ R. 2000. The application of neural networks in biotechnology and biomateriale. Prace Miner., 89: 9-17.

TRZCINSKI W. (ed.). 1989. Systematyka Gleb Polski. Roczniki Gleboznawcze, PWN, Warszawa, 40, 3/4. (in Polish)

WOCKE M.F. 1927. Der Basalt in der Schlesien Lanschaft. Z. F. Vulkanologie Bd. 10, 2: 177-202. 